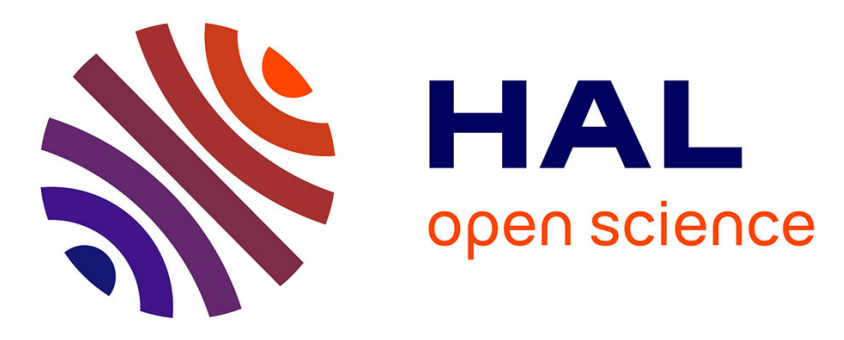

\title{
Cardioprotection against myocardial infarction with PTD-BIR3/RING, a XIAP mimicking protein.
}

Richard Souktani, Sandrine Pons, Christelle Guegan, Omar Bouhidel, Patrick Bruneval, Roland Zini, Chantal Mandet, Brigitte Onteniente, Alain Berdeaux, Bijan Ghaleh

\section{To cite this version:}

Richard Souktani, Sandrine Pons, Christelle Guegan, Omar Bouhidel, Patrick Bruneval, et al.. Cardioprotection against myocardial infarction with PTD-BIR3/RING, a XIAP mimicking protein.: PTDBIR3/RING and cardioprotection. Journal of Molecular and Cellular Cardiology, 2009, 46 (5), pp.7138. 10.1016/j.yjmcc.2009.02.005 . inserm-00385092

\section{HAL Id: inserm-00385092 https://www.hal.inserm.fr/inserm-00385092}

Submitted on 18 May 2009

HAL is a multi-disciplinary open access archive for the deposit and dissemination of scientific research documents, whether they are published or not. The documents may come from teaching and research institutions in France or abroad, or from public or private research centers.
L'archive ouverte pluridisciplinaire HAL, est destinée au dépôt et à la diffusion de documents scientifiques de niveau recherche, publiés ou non, émanant des établissements d'enseignement et de recherche français ou étrangers, des laboratoires publics ou privés. 
Cardioprotection against myocardial infarction

with PTD-BIR3/RING, a XIAP mimicking protein.

by

Richard Souktani $^{4}$, Sandrine Pons ${ }^{1,2}$, Christelle Guegan ${ }^{7}$, Omar Bouhidel ${ }^{1,2}$,

Patrick Bruneval $^{6}$, Roland Zini ${ }^{1,2}$, Chantal Mandet ${ }^{6}$, Brigitte Onteniente ${ }^{5}$,

Alain Berdeaux ${ }^{1,2,3}$, Bijan Ghaleh ${ }^{1,2,3}$.

1- INSERM U 955, Equipe 3, Créteil, F-94010, France

2- Université Paris 12, Laboratoire de Pharmacologie, Faculté de Médecine, Créteil, F-94010, France

3- Groupe Henri Mondor - Albert Chenevier, Fédération de Cardiologie, Créteil, F-94010,

France

4- Plateforme Petit Animal, INSERM U 955, Créteil, F-94010, France

5- INSERM UMR 549, Paris, F-75014, France

6- INSERM U 652, Paris, F-75015, France

7- INSERM U 601, IFR 26, Nantes, F-44000, France

Running head: PTD-BIR3/RING and cardioprotection

Address for correspondance

Pr. Alain BERDEAUX

Laboratoire de Pharmacologie

INSERM U 955, Equipe 3

Faculté de Médecine Paris 12

8 , rue du Général Sarrail

94010 CRETEIL Cedex

France

Tel: 33-1-49.81.36.51

Fax: 33-1-49.98.17.77

E-mail: alain.berdeaux@ inserm.fr 


\begin{abstract}
The purpose of the present study was to investigate the potential cardioprotective effects of an original approach based on the properties of the $\mathrm{X}$ chromosome-linked Inhibitor of Apoptosis (XIAP), the most effective endogenous inhibitor of apoptosis. For this purpose, the C-terminal part of XIAP (BIR3 and RING domains) was fused to the protein transduction domain (PTD) of the HIV1 transactivator of transcription, which confers to fused protein the ability to cross cell membranes. This protein, so-called PTD-BIR3/RING, was administered intravenously in C57BL/6J mice subjected to $30 \mathrm{~min}$ coronary artery occlusion and $24 \mathrm{~h}$ of reperfusion. Administration of PTD-BIR3/RING at $5 \mathrm{~min}$ before and $30 \mathrm{~min}$ after the onset of reperfusion reduced infarct size vs control $(23 \pm 2 \%$ vs $41 \pm 4 \%$ and $27 \pm 4 \%$ vs $41 \pm 3 \%$, respectively, $\mathrm{p}<0.05$ ). Similar reduction in infarct size was observed when PTD-BIR3/RING was administered prior to ischemia $(28 \pm 1 \%$ vs $44 \pm 3 \%)$. In addition to inhibition of caspase-3 and -9 activities, PTD-BIR3/RING induced an inhibition of caspase- 8 and several other actors of the apoptotic pathways. In conclusion, this study demonstrates that the administration of PTD-BIR3/RING reduces myocardial infarct size even when injected during reperfusion through interruption of caspase activation by pharmacologically mimicking endogenous XIAP.
\end{abstract}

Key words: Cardioprotection, infarction, XIAP, reperfusion, caspase activity. 


\section{INTRODUCTION}

Although the current therapeutic strategy during acute myocardial infarction is to reestablish coronary blood flow by angioplasty, thrombolysis or cardiac surgery, the associated morbidity and mortality remain important and therefore require additional cardioprotection. For many years, different approaches such as early and delayed preconditioning $(1,2)$, pharmacological cardioprotection (3-6) or more recently postconditioning, i.e., brief interruptions of reperfusion with short episodes of myocardial ischemia (7) have been extensively investigated in this regard. Interestingly, clinical studies have demonstrated the benefit of ischemic postconditioning in patients with acute myocardial infarction (8-10). However, the clinical translation of almost all these strategies is limited by the schedule of treatment as they must be applied either before the onset of ischemia or within the very first minutes of reperfusion (11-13) and also by the fact that postconditioning is restricted to patients who are undergoing percutaneous coronary intervention. Therefore, the development of other cardioprotective strategies still remains a major challenge.

Cell death after ischemia-reperfusion occurs at least by necrosis and apoptosis. Apoptosis is a programmed cell death controlled by the death receptor, the mitochondrial pathways through caspase activation and also endogenous regulators of apoptotic cell death. In this setting, XIAP (X chromosome-linked Inhibitor of Apoptosis) is a major inhibitor of apoptosis in cardiomyocyte (14) and ischemia or hypoxia are known to reduce XIAP expression (15, 16). XIAP possesses three baculovirus IAP repeat (BIR1, BIR2 and BIR3) domains and a RING (really interesting new gene) domain. The BIR3 domain interacts with caspase-9 (17) while the RING domain possesses a E3 ligase activity and is implicated in proteasome-related degradation of a number of substrates that include caspase-3 (18). Among the endogenous inhibitors of apoptosis such as IAP1, IAP2, ILP2, MLIAP, NIAP, XIAP is the best 
characterized of mammalian IAPs and it is also the most potent and versatile of these regulators of cell death $(19,20)$. XIAP mRNA has been observed in all adult and fetal tissues examined except peripheral blood leukocytes, indicating that it is an ubiquitous expressed member of the IAP family (21).

Accordingly, the aim of the present study was to examine whether the C-terminal part of XIAP (BIR3 and RING domains) fused to the protein transduction domain (PTD) of the TATfusion system (HIV1 transactivator of transcription), i.e., PTD-BIR3/RING, could protect the myocardium against infarction. Fusion of BIR3/RING domains with TAT confers to this aminoacidic sequence the ability to cross cell membranes with a great efficacy (22), thereby decreasing the amount of protein needed for biological efficacy. We hypothesized that a beneficial effect could be observed when PTD-BIR3/RING is administered before but also during reperfusion, by pharmacologically mimicking the effects of XIAP. In addition, we also investigated several proteins that play important roles in the apoptotic transduction signaling along with caspase activities. 


\section{METHODS}

The experiments were performed in accordance with the official regulations of the French Ministry of Agriculture. The authors have been granted a license from the institutional office "Préfecture du Val de Marne" (France) to conduct animal research (n A 94-028-245).

\section{Generation, production and purification of PTD-BIR3/RING}

A construct encoding the BIR3/RING domains of XIAP was amplified from the cDNA of the entire reading frame of rat XIAP and purified fragments were cloned into the $X h o \mathrm{I} / E c o \mathrm{RI}$ sites of the pTAT-HA vector (23). The final cDNA encoded a protein comprising a 6-histidine residues tag, the PTD sequence of TAT, a hemagglutinin (HA) tag and BIR3/RING sequences. Plasmids, i.e., the PTD-BIR3/RING and PTD-HA alone were expressed in the $E$. coli strain BL21(DE3) pLysS (Stratagene, La Jolla, CA, USA) as previously described (23). Protein production was induced by addition of $500 \mu \mathrm{M}$ isopropyl 1 -thio- $\beta$-D-galactoside. Proteins were extracted in $8 \mathrm{M}$ urea HEPES buffer and were purified using a Ni-NTA superflow agarose column (Qiagen, Hilden, Germany). Salt was removed using dialysis (Pierce Biotechnology Inc, Rockford, IL, USA) and proteins were collected in a solution containing phosphate buffered saline. The molecular weight of purified proteins was verified by Coomassie blue staining of electrophoresis gels.

\section{Animal model of myocardial infarction}

Male C57BL6/J mice (6-8 weeks) were anesthetized by intraperitoneal injection of pentobarbital sodium $(50 \mathrm{mg} / \mathrm{kg})$, intubated and ventilated mechanically. The body temperature was measured using a rectal probe and was maintained at $37^{\circ} \mathrm{C}$ with a blanket connected to an homeothermic regulator (Homeo-blanket system 50-7221F, Harvard Apparatus, Les Ulis, France). A small catheter was inserted into a jugular vein for 
administration of the treatment and a thoracotomy was performed. A coronary artery occlusion and reperfusion was achieved with an 8-0 Prolene thread placed around the left coronary artery as previously described (24). Myocardial ischemia was confirmed by ST segment deviation of the electrocardiogram and the occurrence of regional cyanosis. Reperfusion was confirmed by visualisation of hyperemic response and the chest was closed in layers.

\section{Experimental protocol}

The experimental protocols are shown in figure 1 . To determine the effects of PTDBIR3/RING on myocardial infarct size, mice underwent 30 min of coronary artery occlusion followed by $24 \mathrm{~h}$ of reperfusion. In these experiments, PTD-BIR3/RING $(0.8 \mu \mathrm{g} / \mathrm{g})$ was injected intravenously either $5 \mathrm{~min}$ before ischemia as well as $5 \mathrm{~min}$ before and $30 \mathrm{~min}$ after the onset of reperfusion. The dose of $0.8 \mu \mathrm{g} / \mathrm{g}$ was chosen on the basis of preliminary experiments investigating the infarct-limiting effects of increasing doses of PTD-BIR3/RING. The control groups were treated with vehicle (phosphate buffer saline) 5 min before ischemia, $5 \mathrm{~min}$ before and $30 \mathrm{~min}$ after the onset of reperfusion. Although it would have been more appropriate to use PTD-HA in the control mice, it is unlikely that the use of phosphate buffer saline represents an experimental biais as we verified that administration of PTD-HA (1 $\mathrm{mg} / \mathrm{ml}$ and $0.8 \mu \mathrm{g} / \mathrm{g}$ ) alone at $30 \mathrm{~min}$ of reperfusion did not elicit proper effects on myocardial infarct size $(40 \pm 4 \%, \mathrm{n}=6$ vs $41 \pm 3 \%, \mathrm{n}=9$ for PTD-HA and phosphate buffer saline-treated mice, respectively).

\section{Assessment of infarct size}

At the end of the $24 \mathrm{~h}$ reperfusion period, the coronary artery was reoccluded at the previous site of occlusion. The area at risk was identified by negative Evan's blue dye staining and the infarct area was identified by triphenyltetrazolium chloride (TTC) negative 
staining. The area at risk was expressed as a percentage of the left ventricle weight. The infarcted area was expressed as percentages of the area at risk.

\section{Histology}

Briefly, formalin-fixed slices of infarcted hearts were embedded in paraffin for histological analysis. Five micrometers-thick sections were cut from each paraffin block and stained with H\&E (Hematoxylin\&Eosin).

\section{Caspase activity assay}

In these experiments, PTD-BIR3/RING $(0.8 \mu \mathrm{g} / \mathrm{g})$ was administered at $30 \mathrm{~min}$ of reperfusion and proteins were extracted from left ventricles after $1 \mathrm{~h}, 3 \mathrm{~h}$ and $24 \mathrm{~h}$ of reperfusion and assayed for caspase activity (figure 1). Extraction was also performed in 3 additional mice that did not undergo ischemia-reperfusion. Tissues were homogenized in cold buffer $\left(25 \mathrm{mM}\right.$ HEPES pH 7.5, $5 \mathrm{mM} \mathrm{MgCl}_{2}, 2 \mathrm{mM}$ EDTA, 0.1\% Triton X100, 2mM dithiothreitol, 1mM PMSF, 5 $\mu 1 / \mathrm{ml}$ protease cocktail inhibitor P8849, Sigma-Aldrich, St Louis, MO, USA). Homogenates were centrifuged and supernatants were collected. Proteins $(50 \mu \mathrm{g})$ were incubated in caspase assay buffer (50mM HEPES pH 7.4, 100mM NaCl, $1 \mathrm{mM}$ EDTA, $10 \mathrm{mM}$ dithiothreitol). Enzymatic reaction was started by addition of $0.2 \mathrm{mM}$ of the fluorogenic substrates ac-DEVD-AFC, ac-IETD-AFC, ac-LEHD-AFC (Biomol Research Laboratories, Hambourg, Germany) to caspase-3, caspase-8 and caspase-9, respectively. Fluorescent arbitrary units were converted into $\mu$ moles of $\mathrm{AFC} / \mathrm{h} / \mathrm{mg}$ protein using a standard curve of free AFC (Sigma-Aldrich, St Louis, MO, USA).

\section{Western blot analysis}

In these experiments, PTD-BIR3/RING $(0.8 \mu \mathrm{g} / \mathrm{g})$ was administered at $30 \mathrm{~min}$ of reperfusion and proteins were extracted from left ventricles after $1 \mathrm{~h}$ reperfusion (figure 1). Myocardial 
samples were placed in medium containing $220 \mathrm{mM}$ Mannitol, $70 \mathrm{mM}$ Sucrose, $10 \mathrm{mM}$ HEPES, 1mM EGTA, 1mM PMSF, 5mM NaF, $1 \mathrm{mM} \mathrm{Na} \mathrm{VO}_{4}, 1 \mathrm{mM} \mathrm{Na} 2$ Glycerol 2phosphate, $5 \mu 1 / \mathrm{ml}$ protease inhibitor cocktail (Sigma-Aldrich, St Louis, MO, USA), pH 7.4 at $4{ }^{\circ} \mathrm{C}$. The tissue was minced with scissors and homogenized on ice using a Teflon Potter homogenizer. The homogenate was centrifuged at $1000 \mathrm{~g}$ for $5 \mathrm{~min}$ to remove cellular debris and nuclei. The supernatant was centrifuged for $10 \mathrm{~min}$ at $10000 \mathrm{~g}$ to obtain the mitochondrial pellet. The latter was washed with the same medium and centrifuged at $10000 \mathrm{~g}$ for $10 \mathrm{~min}$. The resulting mitochondrial pellet was resuspended with medium, frozen and thawed several times, and finally sonicated to extract the mitochondrial content. The $10000 \mathrm{~g}$ supernatant was centrifuged at $17600 \mathrm{~g}$ for $30 \mathrm{~min}$. The resulting supernatant was the cytosolic fraction. In order to check for the absence of mitochondrial contamination of the cytosolic fraction, we verified the absence of citrate synthase activity in the cytosolic samples.

Proteins were separated on 10-15\% SDS-polyacrylamide gels using 40-80 $\mu$ g proteins per lane and transferred onto PVDF membranes (Millipore Corporate, Billeria, MA, USA). After blocking with $5 \%$ dry milk in Tris-buffered saline containing $0.1 \%$ Tween-20 (TBS-T), membranes were incubated for $1 \mathrm{~h}$ at room temperature with the following antibodies: rabbit polyclonal anti-phospho-Bad 1:200 (at $\mathrm{Ser}^{136}$ ), rabbit polyclonal anti-Bad 1:250, rabbit polyclonal anti-COX IV 1:3000 (an enzyme localized in the inner mitochondrial membrane used as a mitochondrial loading control; Cell Signaling Technology Inc, Danvers, MA, USA), rabbit polyclonal anti-Bax 1:500, goat polyclonal anti-Smac/DIABLO 1:200, goat polyclonal anti-actin 1:3000 (Santa Cruz Biotechnology Inc, Santa Cruz, CA, USA), goat polyclonal tBid and total Bid 1:1000 (R\&D Systems Inc, Minneapolis, MN, USA). Membranes were then washed three times with TBS-T for $10 \mathrm{~min}$ and subsequently incubated for $1 \mathrm{~h}$ with the appropriate secondary antibody conjugated to horseradish peroxidase (Santa Cruz Biotechnology Inc, Santa Cruz, CA, USA). Bands were visualized with chemiluminescence 
(Pierce ECL Western Blotting Substrate, Pierce Biotechnology Inc, Rockford, IL, USA) and analysed with the Image J software (NIH, Bethesda, MA, USA).

Statistical analysis

All values are expressed as mean \pm SEM for the number of samples indicated in the legends of figures. Comparisons between groups were assessed using ANOVA followed if necessary by Student's $t$-test. Statistical significance was defined as a value of $p<0.05$. 


\section{RESULTS}

\section{Effect of PTD-BIR3/RING on myocardial infarct size}

As shown in table 1, animal body weights and sizes of area at risk were similar among groups. As illustrated in figure 2, PTD-BIR3/RING significantly reduced infarct size as compared to Control when administered $5 \mathrm{~min}$ before and $30 \mathrm{~min}$ after the onset of reperfusion $(23 \pm 2 \%$ vs $41 \pm 4 \%$ and $27 \pm 4 \%$ vs $41 \pm 3 \%$, respectively). Similar reduction in infarct size was observed when PTD-BIR3/RING was administered prior to ischemia $(28 \pm 1 \%$ vs $44 \pm 3 \%)$.

\section{Histology}

In contrast with the major difference in infarct size between the two groups, histological analysis only revealed moderate different patterns of lesions within the infarct as shown in figure 3. In control mice, the main focus of infarction demonstrated a homogenous pattern of cell death whereas in PTD-BIR3/RING treated mice, it was less homogenous and made of patchy foci of cell death.

\section{Caspase activities}

In control mice, caspase-3, caspase- 8 and caspase- 9 activities were increased at $3 \mathrm{~h}$ of reperfusion as illustrated in figure 4 . When PTD-BIR3/RING was administered at $30 \mathrm{~min}$ of reperfusion, these increases were significantly blunted by PTD-BIR3/RING. After $24 \mathrm{~h}$ of reperfusion, all caspase activities were similar in the PTD-BIR-3/RING and control mice and these values were similar to those observed in mice that did not suffer ischemia-reperfusion (61 $\pm 14,69 \pm 7$ and $7 \pm 1 \mu \mathrm{M} \mathrm{AFC/h/mg} \mathrm{protein} \mathrm{for} \mathrm{caspase-3,}-8$ and -9 , respectively). 
Western blot analysis

As illustrated in figure 5, the phosphorylated $\mathrm{Bad} / \mathrm{Bad}$ ratio was significantly increased in PTD-BIR3/RING treated mice $(+342 \%)$ as compared to Control. Concomitantly with inhibition of caspase- 8 activity, we observed that the ratio of truncated Bid to total Bid was significantly reduced by PTD-BIR3/RING (-41\%). In addition, as several pro-apoptotic proteins are known to translocate between the cytosol and the mitochondria, we analysed their subcellular location. Analysis of the cytosolic and mitochondrial fractions revealed that PTDBIR3/RING significantly increased the Bax cytosolic to mitochondrial ratio as compared to Control. Finally, Smac/DIABLO cytosolic to mitochondrial ratios were similar between the two groups. 


\section{DISCUSSION}

The present study demonstrates that the administration of BIR3/RING using the protein transduction domain (PTD) of the TAT-fusion system, i.e., PTD-BIR3/RING up to $30 \mathrm{~min}$ during reperfusion significantly reduces myocardial infarct size in mice subjected to $30 \mathrm{~min}$ coronary artery occlusion. The novel finding is that the previously ischemic myocardium can be salvaged by pharmacologically mimicking the effects of XIAP during reperfusion. This is consistent with a previous report demonstrating that overexpression of the endogenous inhibitor IAP-2 significantly reduces myocardial infarct size and apoptosis (25). The beneficial effect observed in our study was achieved through inhibiting caspase-mediated cell death pathways. Besides inhibition of caspase-3 and -9, PTD-BIR3/RING also blunted the increase in caspase- 8 activity. This was associated with the reduction of ischemia-induced truncation of Bid, a target of caspase-8, and inactivation of key players of the apoptotic mitochondrial pathway such as the Bcl-2 family members Bax and Bad. Interestingly, PTDBIR3/RING administered prior to ischemia or reperfusion did not afford a higher degree of protection than when administered at reperfusion suggesting that the cardioprotective effect of PTD-BIR3/RING is mainly related due to the interruption of deleterious signaling pathways that are activated during reperfusion.

Among numerous proteins that are known to regulate caspase activity, XIAP is the most potent inhibitor of apoptosis (26). The PTD peptide of the HIV1-TAT can enter into the cells efficiently when added exogenously and allows cellular delivery of macromolecules. In the present study, PTD-BIR3/RING had kept its main biological activity as its administration abolished the increases in caspase- 3 and caspase-9 activities during reperfusion. More importantly, it has been demonstrated, using purified recombinant proteins, that the BIR3 domain is the minimal region of XIAP needed for potent caspase-9 inhibition (17) and that the 
RING domain of XIAP is essential for destruction of caspase- 3 through the proteasome (18, 21). Caspase-9 is an initiator caspase that is in the first wave of activation when apoptosis is triggered. Caspase- 3 is activated through the action of initiator caspases and its activation results in irreversible cell damage and death (27). Histological analysis revealed differential tissular aspects as, in contrast to control mice, the main focus of infarct in the PTDBIR3/RING treated mice was less homogeneous suggesting patchy areas of salvaged tissues. It should also be considered that Smac/DIABLO is released by the mitochondria into the cytosol where it binds to IAPs, displacing caspases and thus enhancing the apoptotic signal (28). In our experimental conditions, we observed that the cytosolic to mitochondrial ratio of Smac/DIABLO was unchanged in PTD-BIR3/RING treated mice. We cannot exclude that part of PTD-BIR3/RING was inhibited by Smac/DIABLO. Nevertheless, the effects observed in PTD-BIR3/RING treated animals indicate that the amount of administered PTDBIR3/RING override the endogenous inhibitory effect of Smac/DIABLO.

We also demonstrated for the first time that PTD-BIR3/RING inhibits caspase-8 activity. This result is of great importance as caspase- 8 is at crossroads between the extrinsic and intrinsic apoptosis pathways (27) and plays multiple roles in apoptosis (29). Besides being an initiator caspase of the death-receptors pathway, caspase- 8 exhibits a direct protease activity in the nucleus and plays an amplificatory role of the mitochondrial apoptotic pathway by cleavage and activation of the Bcl-2-related pro-apoptotic molecule Bid. Truncated Bid activates another member of the $\mathrm{Bcl}-2$ family, Bax, which translocates into the outer mitochondrial membrane and participates to the pore formation. The resulting release of apoptogenic factors activates effector caspases. Consistent with its protective effect, PTDBIR3/RING induced a significant decrease in truncated Bid and reduced the translocation of Bax from the cytosol to the mitochondria as demonstrated by the reduction in Bax cytosolic to 
mitochondrial ratio. PTD-BIR3/TING was also responsible for an increase in the phosphorylation of Bad favouring its cytosolic sequestration.

Although we did not specifically investigate the mechanisms of caspase- 8 inhibition by PTD-BIR3/RING, some hypotheses can be raised. CARPs (caspase-8 and -10 associated RING proteins) represent a family of anti-apoptotic proteins that specifically bind to and regulate DED (death effector domain) caspases such as caspase-8. Their RING domain possesses a high homology with the IAP family and exhibits a E3 ligase activity which may contribute to the ubiquitin-mediated proteolysis of DED caspases (30). It has also been demonstrated in epithelial cancer cell lines that activated caspase-3 cleaves and activates caspase- 8 (31). One could therefore speculate that inhibition of caspase- 8 activity by PTDBIR3/RING may involve the E3 ubiquitin ligase activity of its RING domain or an indirect inhibition through caspase-3 inhibition. However, investigation of these issues was beyond the scope of this study.

It is also important to emphasize that the beneficial effects of PTD-BIR3/RING were still observed when administered up to $30 \mathrm{~min}$ after the onset of reperfusion. To date, the so-called postconditioning or the administration of pharmacological agents have to be started within the very first minutes of reperfusion to be efficient. Indeed, starting administration of the adenosine agonist agent AMP579 after 10 min of reperfusion or postconditioning after the first minutes of reperfusion is too late $(11,12)$. Such delayed cardioprotective effect of PTDBIR3/RING is rather similar to that reported with other pharmacological strategies $(32,33)$. Finally, previous studies have also reported the beneficial effects of several caspase inhibitors but the administration of the blockers was started before the onset of reperfusion (34-37).

In conclusion, this study demonstrates that the administration of PTD-BIR3/RING reduces myocardial infarct size even when administered during reperfusion. PTD-BIR3/RING exerts 
its cardioprotective effect through the interruption of caspase activation by pharmacologically mimicking endogenous XIAP. 


\section{ACKNOWLEDGEMENTS}

This study was supported by grants from ACI 2003 "Plateforme d'exploration fonctionnelle thématisée" [R03020JJ] and INSERM transfert [03202A10]. The authors wish to thank Valérie Martin for her technical help. 


\section{REFERENCES}

[1] Murry CE, Jennings RB, Reimer KA. Preconditioning with ischemia: a delay of lethal cell injury in ischemic myocardium. Circulation 1986; 74: 1124-36.

[2] Marber MS, Walker DM, Eveson DJ, Walker JM, Yellon DM. A single five minute period of rapid atrial pacing fails to limit infarct size in the in situ rabbit heart. Cardiovasc Res 1993; 27: 597-601.

[3] Jonassen AK, Sack MN, Mjos OD, Yellon DM. Myocardial protection by insulin at reperfusion requires early administration and is mediated via Akt and p70s6 kinase cellsurvival signaling. Circ Res 2001; 89: 1191-8.

[4] Xu Z, Yang XM, Cohen MV, Neumann T, Heusch G, Downey JM. Limitation of infarct size in rabbit hearts by the novel adenosine receptor agonist AMP 579 administered at reperfusion. J Mol Cell Cardiol 2000; 32: 2339-47.

[5] Bell RM, Yellon DM. Bradykinin limits infarction when administered as an adjunct to reperfusion in mouse heart: the role of PI3K, Akt and eNOS. J Mol Cell Cardiol 2003; 35: 185-93.

[6] Gross ER, Hsu AK, Gross GJ. Opioid-induced cardioprotection occurs via glycogen synthase kinase beta inhibition during reperfusion in intact rat hearts. Circ Res 2004; 94: 9606.

[7] Zhao ZQ, Corvera JS, Halkos ME, Kerendi F, Wang NP, Guyton RA, Vinten-Johansen J. Inhibition of myocardial injury by ischemic postconditioning during reperfusion: comparison with ischemic preconditioning. Am J Physiol Heart Circ Physiol 2003; 285: H579-88. 
[8] Darling CE, Solari PB, Smith CS, Furman MI, Przyklenk K. 'Postconditioning' the human heart: multiple balloon inflations during primary angioplasty may confer cardioprotection. Basic Res Cardiol 2007; 102: 274-8.

[9] Staat P, Rioufol G, Piot C, Cottin Y, Cung TT, L'Huillier I, Aupetit JF, Bonnefoy E, Finet G, Andre-Fouet X, Ovize M. Postconditioning the human heart. Circulation 2005; 112: 21438.

[10] Thibault H, Piot C, Staat P, Bontemps L, Sportouch C, Rioufol G, Cung TT, Bonnefoy E, Angoulvant D, Aupetit JF, Finet G, Andre-Fouet X, Macia JC, Raczka F, Rossi R, Itti R, Kirkorian G, Derumeaux G, Ovize M. Long-term benefit of postconditioning. Circulation 2008; 117: 1037-44.

[11] Kin H, Zhao ZQ, Sun HY, Wang NP, Corvera JS, Halkos ME, Kerendi F, Guyton RA, Vinten-Johansen J. Postconditioning attenuates myocardial ischemia-reperfusion injury by inhibiting events in the early minutes of reperfusion. Cardiovasc Res 2004; 62: 74-85.

[12] Xu Z, Downey JM, Cohen MV. Timing and duration of administration are crucial for antiinfarct effect of AMP 579 infused at reperfusion in rabbit heart. Heart Dis 2003; 5: 36871.

[13] Piot C, Croisille P, Staat P, Thibault H, Rioufol G, Mewton N, Elbelghiti R, Cung TT, Bonnefoy E, Angoulvant D, Macia C, Raczka F, Sportouch C, Gahide G, Finet G, AndreFouet X, Revel D, Kirkorian G, Monassier JP, Derumeaux G, Ovize M. Effect of cyclosporine on reperfusion injury in acute myocardial infarction. N Engl J Med 2008; 359: 473-81. 
[14] Potts MB, Vaughn AE, McDonough H, Patterson C, Deshmukh M. Reduced Apaf-1 levels in cardiomyocytes engage strict regulation of apoptosis by endogenous XIAP. J Cell Biol 2005; 171: 925-30.

[15] Lyn D, Bao S, Bennett NA, Liu X, Emmett NL. Ischemia elicits a coordinated expression of pro-survival proteins in mouse myocardium. ScientificWorldJournal 2002; 2: 997-1003.

[16] Shilkrut M, Yaniv G, Asleh R, Levy AP, Larisch S, Binah O. Tyrosine kinases inhibitors block Fas-mediated deleterious effects in normoxic and hypoxic ventricular myocytes. J Mol Cell Cardiol 2003; 35: 1229-40.

[17] Sun C, Cai M, Meadows RP, Xu N, Gunasekera AH, Herrmann J, Wu JC, Fesik SW. NMR structure and mutagenesis of the third Bir domain of the inhibitor of apoptosis protein XIAP. J Biol Chem 2000; 275: 33777-81.

[18] Suzuki Y, Nakabayashi Y, Takahashi R. Ubiquitin-protein ligase activity of X-linked inhibitor of apoptosis protein promotes proteasomal degradation of caspase- 3 and enhances its anti-apoptotic effect in Fas-induced cell death. Proc Natl Acad Sci U S A 2001; 98: 8662-7.

[19] Deveraux QL, Reed JC. IAP family proteins--suppressors of apoptosis. Genes Dev 1999; 13: 239-52.

[20] Holcik M, Gibson H, Korneluk RG. XIAP: apoptotic brake and promising therapeutic target. Apoptosis 2001; 6: 253-61.

[21] Liston P, Roy N, Tamai K, Lefebvre C, Baird S, Cherton-Horvat G, Farahani R, McLean M, Ikeda JE, MacKenzie A, Korneluk RG. Suppression of apoptosis in mammalian cells by NAIP and a related family of IAP genes. Nature 1996; 379: 349-53. 
[22] Fawell S, Seery J, Daikh Y, Moore C, Chen LL, Pepinsky B, Barsoum J. Tat-mediated delivery of heterologous proteins into cells. Proc Natl Acad Sci U S A 1994; 91: 664-8.

[23] Dietz GP, Kilic E, Bahr M. Inhibition of neuronal apoptosis in vitro and in vivo using TAT-mediated protein transduction. Mol Cell Neurosci 2002; 21: 29-37.

[24] Michael LH, Entman ML, Hartley CJ, Youker KA, Zhu J, Hall SR, Hawkins HK, Berens $\mathrm{K}$, Ballantyne CM. Myocardial ischemia and reperfusion: a murine model. Am J Physiol 1995; 269: H2147-54.

[25] Chua CC, Gao J, Ho YS, Xiong Y, Xu X, Chen Z, Hamdy RC, Chua BH. Overexpression of IAP-2 attenuates apoptosis and protects against myocardial ischemia/reperfusion injury in transgenic mice. Biochim Biophys Acta 2007; 1773: 577-83.

[26] Vaux DL, Silke J. Mammalian mitochondrial IAP binding proteins. Biochem Biophys Res Commun 2003; 304: 499-504.

[27] Leblanc V, Dery MC, Shooner C, Asselin E. Opposite regulation of XIAP and Smac/DIABLO in the rat endometrium in response to 17 beta-estradiol at estrus. Reprod Biol Endocrinol 2003; 1: 59.

[28] Verhagen AM, Ekert PG, Pakusch M, Silke J, Connolly LM, Reid GE, Moritz RL, Simpson RJ, Vaux DL. Identification of DIABLO, a mammalian protein that promotes apoptosis by binding to and antagonizing IAP proteins. Cell 2000; 102: 43-53.

[29] Benchoua A, Couriaud C, Guegan C, Tartier L, Couvert P, Friocourt G, Chelly J, Menissier-de Murcia J, Onteniente B. Active caspase- 8 translocates into the nucleus of apoptotic cells to inactivate poly(ADP-ribose) polymerase-2. J Biol Chem 2002; 277: 34217 22. 
[30] McDonald ER, 3rd, El-Deiry WS. Suppression of caspase-8- and -10-associated RING proteins results in sensitization to death ligands and inhibition of tumor cell growth. Proc Natl Acad Sci U S A 2004; 101: 6170-5.

[31] Tang D, Lahti JM, Kidd VJ. Caspase-8 activation and bid cleavage contribute to MCF7 cellular execution in a caspase-3-dependent manner during staurosporine-mediated apoptosis. J Biol Chem 2000; 275: 9303-7.

[32] Doukas J, Wrasidlo W, Noronha G, Dneprovskaia E, Fine R, Weis S, Hood J, Demaria A, Soll R, Cheresh D. Phosphoinositide 3-kinase gamma/delta inhibition limits infarct size after myocardial ischemia/reperfusion injury. Proc Natl Acad Sci U S A 2006; 103: 19866-71.

[33] Gao E, Boucher M, Chuprun JK, Zhou RH, Eckhart AD, Koch WJ. Darbepoetin alfa, a long-acting erythropoietin analog, offers novel and delayed cardioprotection for the ischemic heart. Am J Physiol Heart Circ Physiol 2007; 293: H60-8.

[34] Mocanu MM, Baxter GF, Yellon DM. Caspase inhibition and limitation of myocardial infarct size: protection against lethal reperfusion injury. Br J Pharmacol 2000; 130: 197-200.

[35] Huang JQ, Radinovic S, Rezaiefar P, Black SC. In vivo myocardial infarct size reduction by a caspase inhibitor administered after the onset of ischemia. Eur J Pharmacol 2000; 402: $139-42$

[36] Holly TA, Drincic A, Byun Y, Nakamura S, Harris K, Klocke FJ, Cryns VL. Caspase inhibition reduces myocyte cell death induced by myocardial ischemia and reperfusion in vivo. J Mol Cell Cardiol 1999; 31: 1709-15.

[37] Yaoita H, Ogawa K, Maehara K, Maruyama Y. Attenuation of ischemia/reperfusion injury in rats by a caspase inhibitor. Circulation 1998; 97: 276-81. 


\section{LEGEND OF FIGURES}

\section{Figure 1}

Experimental protocols (CAO: coronary artery occlusion; CAR: coronary artery reperfusion) in mice receiving either vehicle (Control) or PTD-BIR3/RING (BIR, $0.8 \mu \mathrm{g} / \mathrm{g}$ ). The arrows indicate the timing of PTD-BIR3/RING administration.

\section{Figure 2}

Individual and averaged values of infarct size expressed as percentage of the area at risk (AAR) measured at $24 \mathrm{~h}$ of coronary artery reperfusion (CAR) after 30 min coronary artery occlusion (CAO) in Control (C) and PTD-BIR3/RING-treated mice (BIR, 0.8 $\mu \mathrm{g} / \mathrm{g}) .{ }^{*}, \mathrm{p}<0.05$ vs corresponding Control.

\section{Figure 3}

Histological analysis with H\&E staining in control mice (panels A-C) and PTD-BIR3/RING treated mice (panels D-F).

A: At low magnification the main focus of infarction is quite homogeneous and made of dead cells. On the left of the figure, note the viable area of the myocardium $($ bar $=100 \mu \mathrm{m})$; B: Higher magnification clearly shows the homogeneous pattern of cell death within the main infarct focus (bar $=50 \mu \mathrm{m}) ; \mathrm{C}$ : At the periphery of the main focus, note the patchy pattern mode of individual or grouped cells $(\mathrm{bar}=50 \mu \mathrm{m})$; $\mathrm{D}$ : At low magnification, the main focus of infarction is less homogeneous and made of patchy areas of cell death (bar $=100 \mu \mathrm{m})$. E: Higher magnification confirms the panel D (bar $=50 \mu \mathrm{m})$. F: At the periphery of the main infarct focus, note the patchy pattern of cell death $(\mathrm{bar}=50 \mu \mathrm{m})$. 


\section{Figure 4}

Caspase activities in Control (open bars) and PTD-BIR3/RING-treated mice (shaded bars) at $30 \mathrm{~min}$ of reperfusion. Measurements were performed at $1 \mathrm{~h}, 3 \mathrm{~h}$ and $24 \mathrm{~h}$ of coronary artery reperfusion $(\mathrm{CAR}){ }^{*}, \mathrm{p}<0.05$ vs corresponding Control.

Figure 5

Representative Western blots showing that PTD-BIR3/RING (BIR, shaded bars) administered at $30 \mathrm{~min}$ of reperfusion induced significant increase of phosphorylated $\mathrm{Bad} / \mathrm{Bad}$, $\mathrm{Bax}$ cytosolic to mitochondrial ratio as well as reduction in Bid truncation as compared to Control (C, open bars). Smac/DIABLO cytosolic to mitochondrial ratio was similar between PTDBIR3/RING and Control. *, $\mathrm{p}<0.05$ vs corresponding Control. 
Table 1 . Body weights and areas at risk

\begin{tabular}{|c|c|c|c|}
\hline Timing of administration & $\mathrm{n}$ & BW $(g)$ & $\operatorname{AAR}(\% \mathrm{LV})$ \\
\hline \multicolumn{4}{|l|}{5 min before $C A O$} \\
\hline Control & 5 & $25 \pm 2$ & $37 \pm 3$ \\
\hline PTD-BIR3/RING & 4 & $24 \pm 1$ & $38 \pm 4$ \\
\hline \multicolumn{4}{|l|}{5 min before $C A R$} \\
\hline Control & 6 & $26 \pm 3$ & $40 \pm 3$ \\
\hline PTD-BIR3/RING & 6 & $23 \pm 1$ & $36 \pm 3$ \\
\hline \multicolumn{4}{|l|}{$30 \min C A R$} \\
\hline Control & 9 & $26 \pm 3$ & $39 \pm 3$ \\
\hline PTD-BIR3/RING & 9 & $27 \pm 3$ & $45 \pm 3$ \\
\hline
\end{tabular}

Values are mean \pm s.e.m.

AAR: area at risk; BW: body weight; CAO: coronary artery occlusion

CAR: coronary artery reperfusion; $\mathrm{LV}$ : left ventricle. 


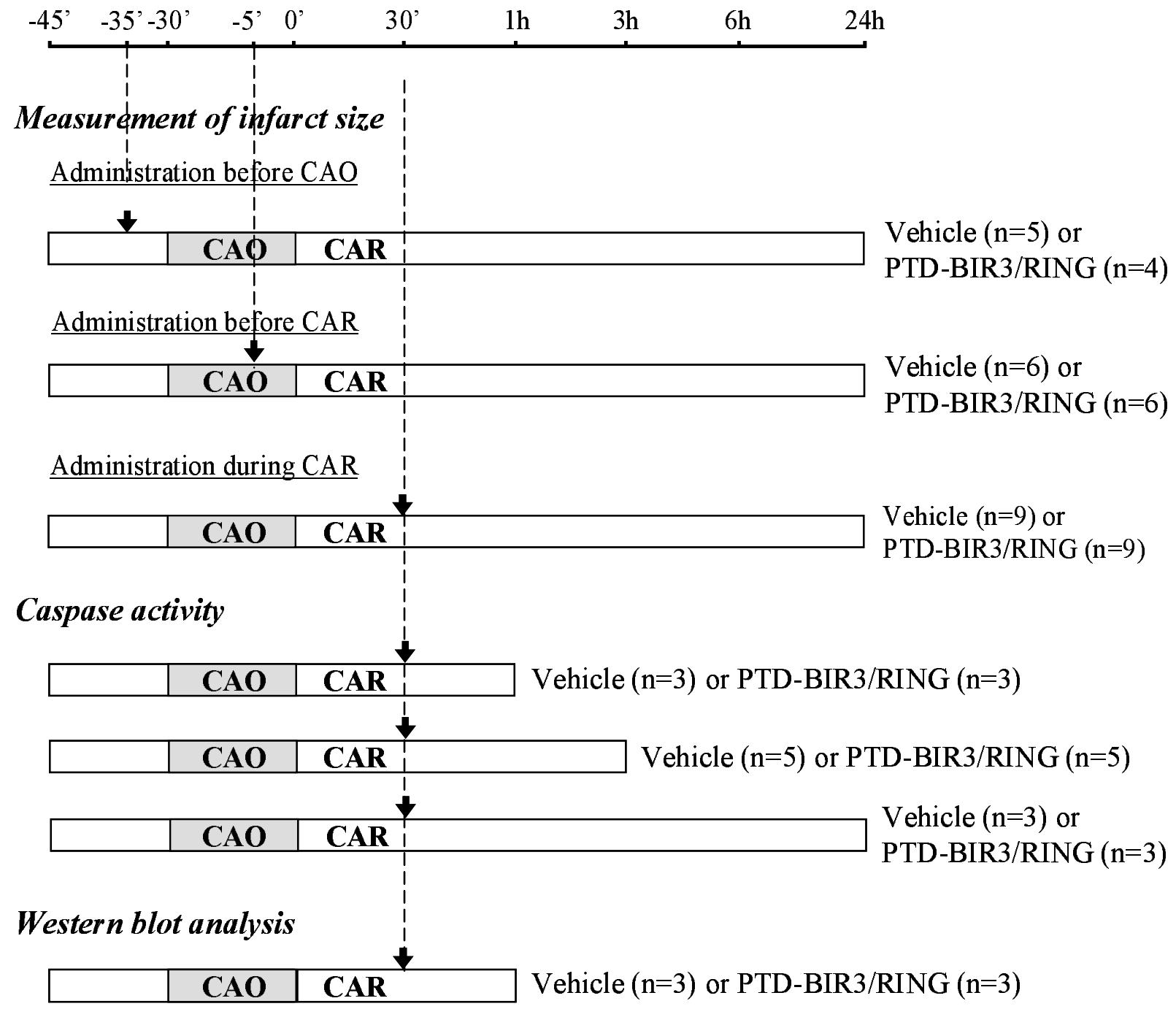



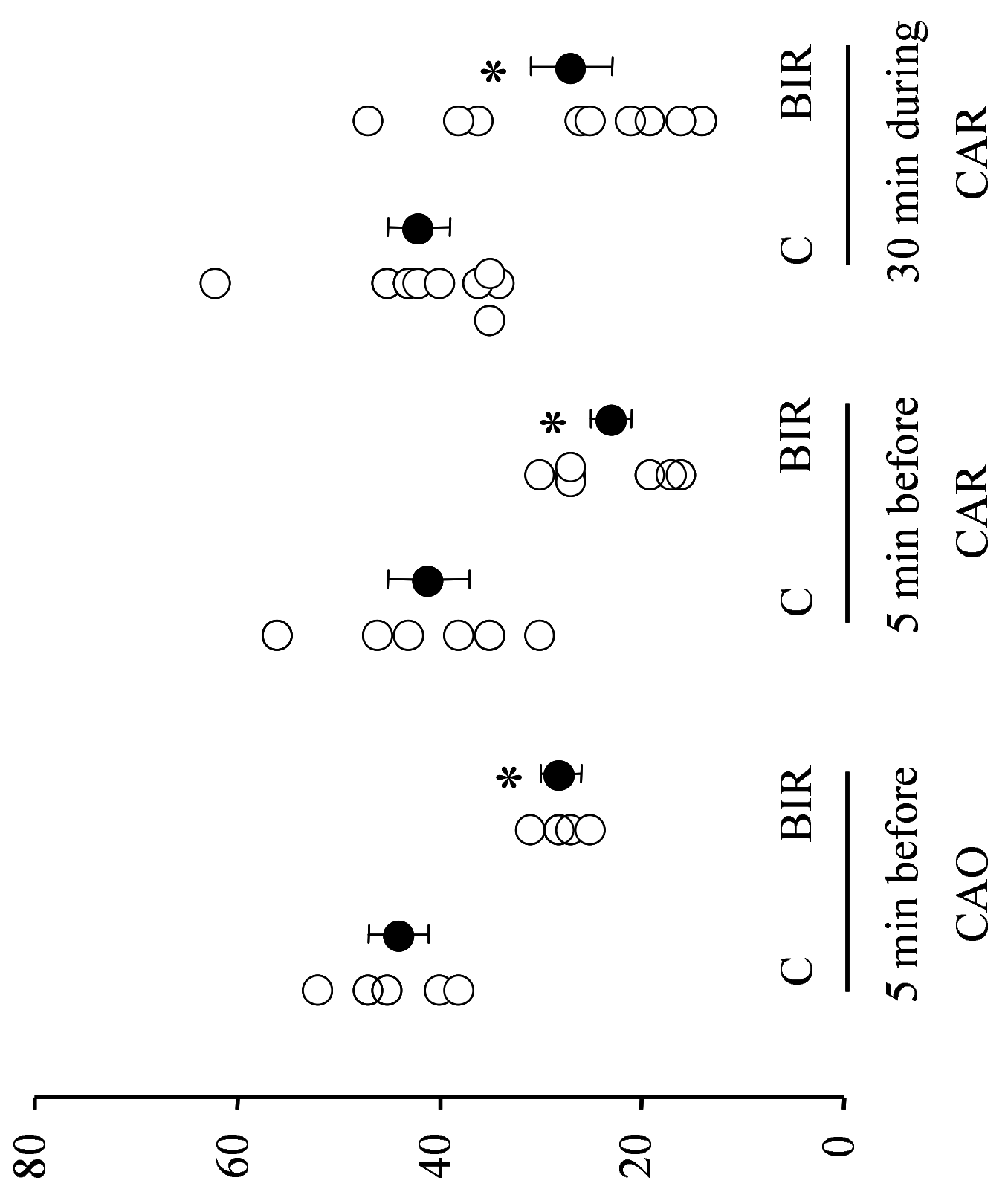

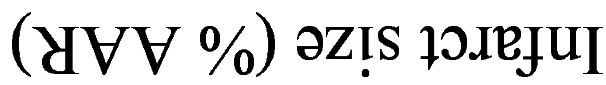




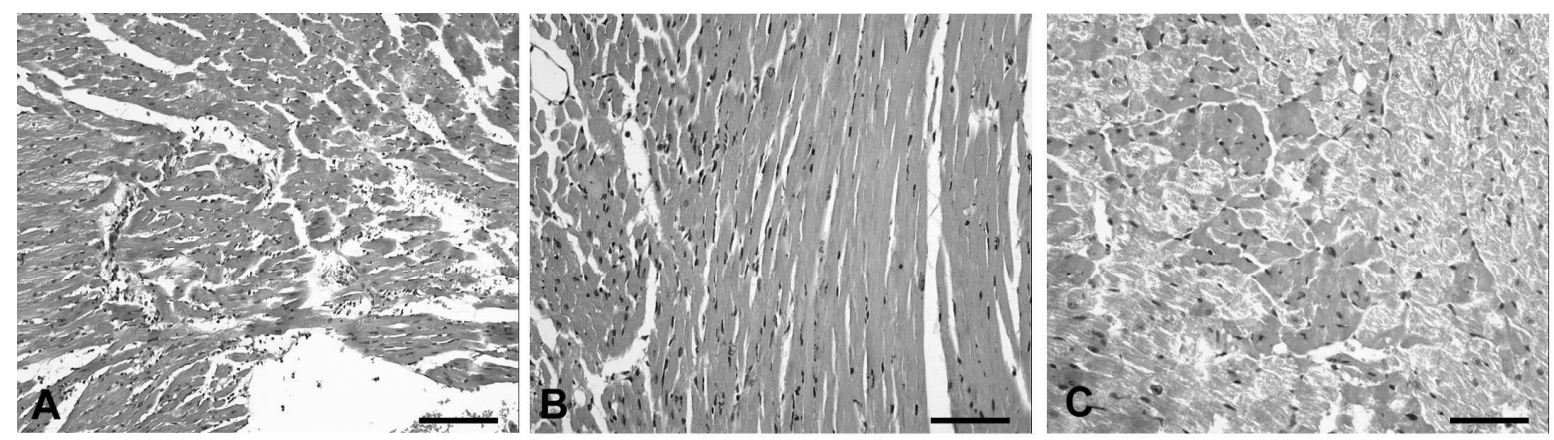

CONTROL

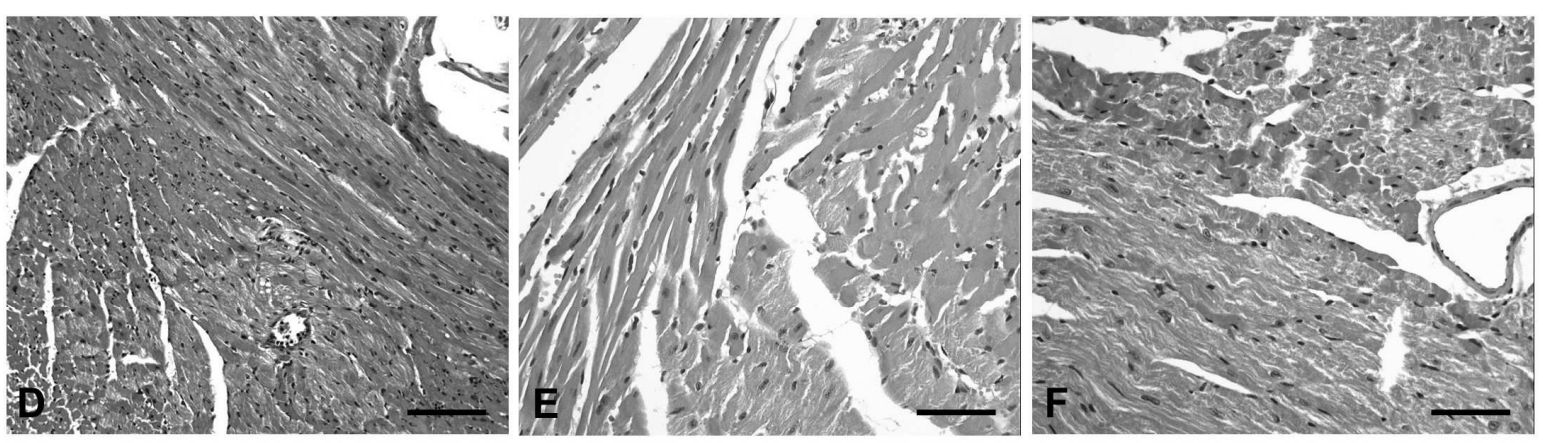

BIR 


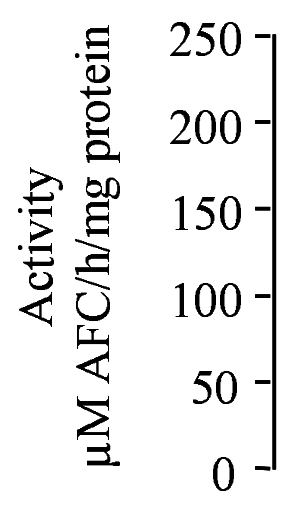

caspase-3
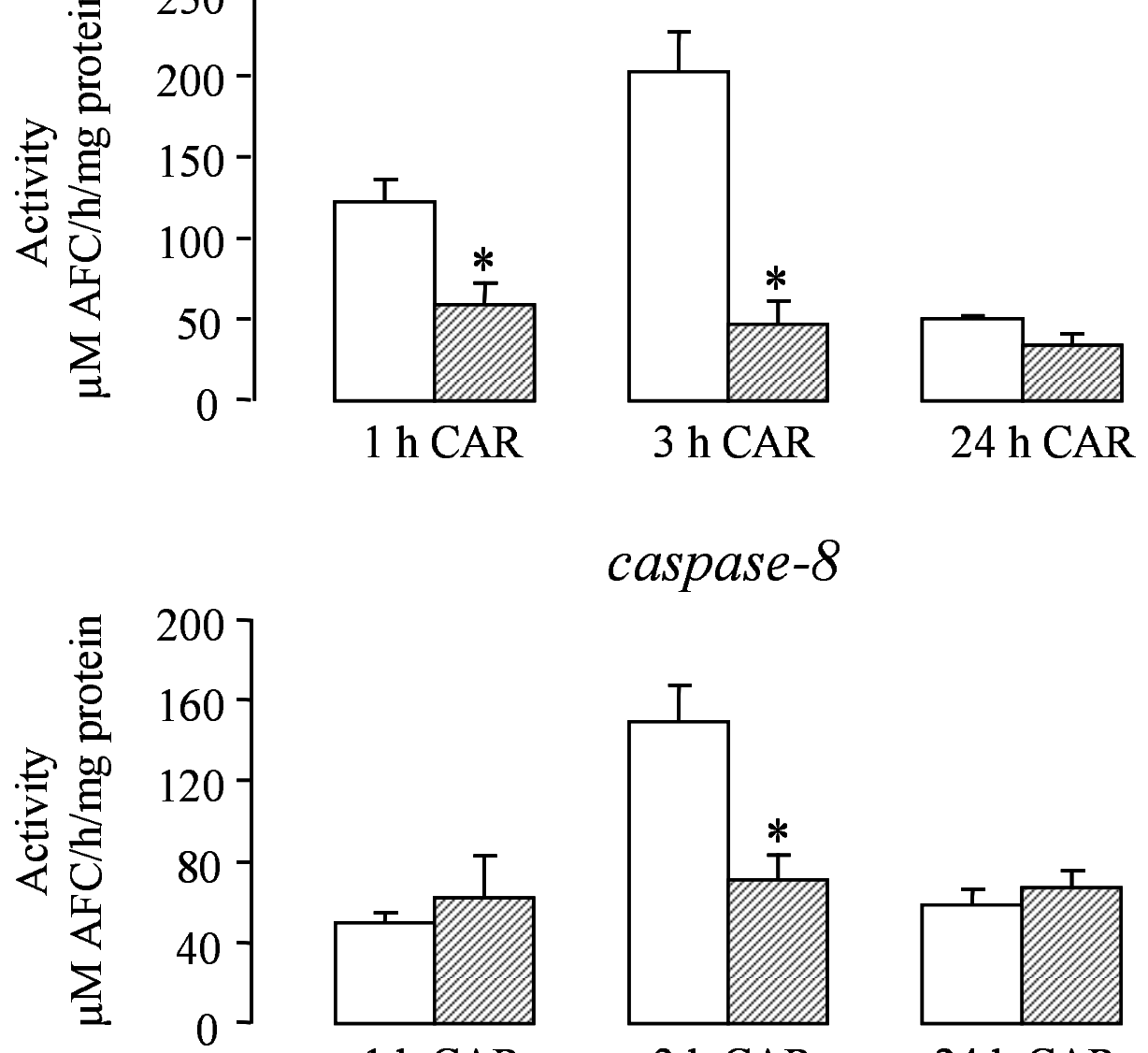

$$
\text { caspase-8 }
$$

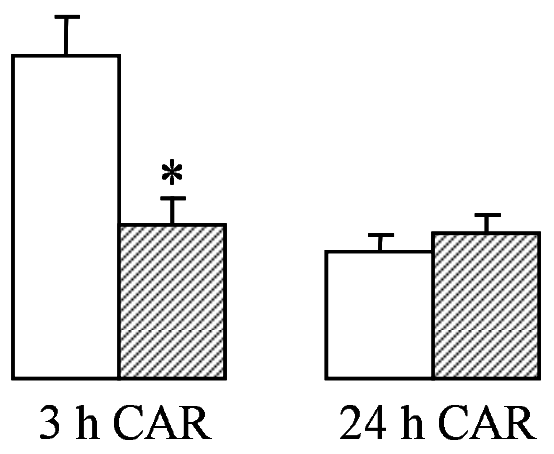

$$
\text { caspase-9 }
$$
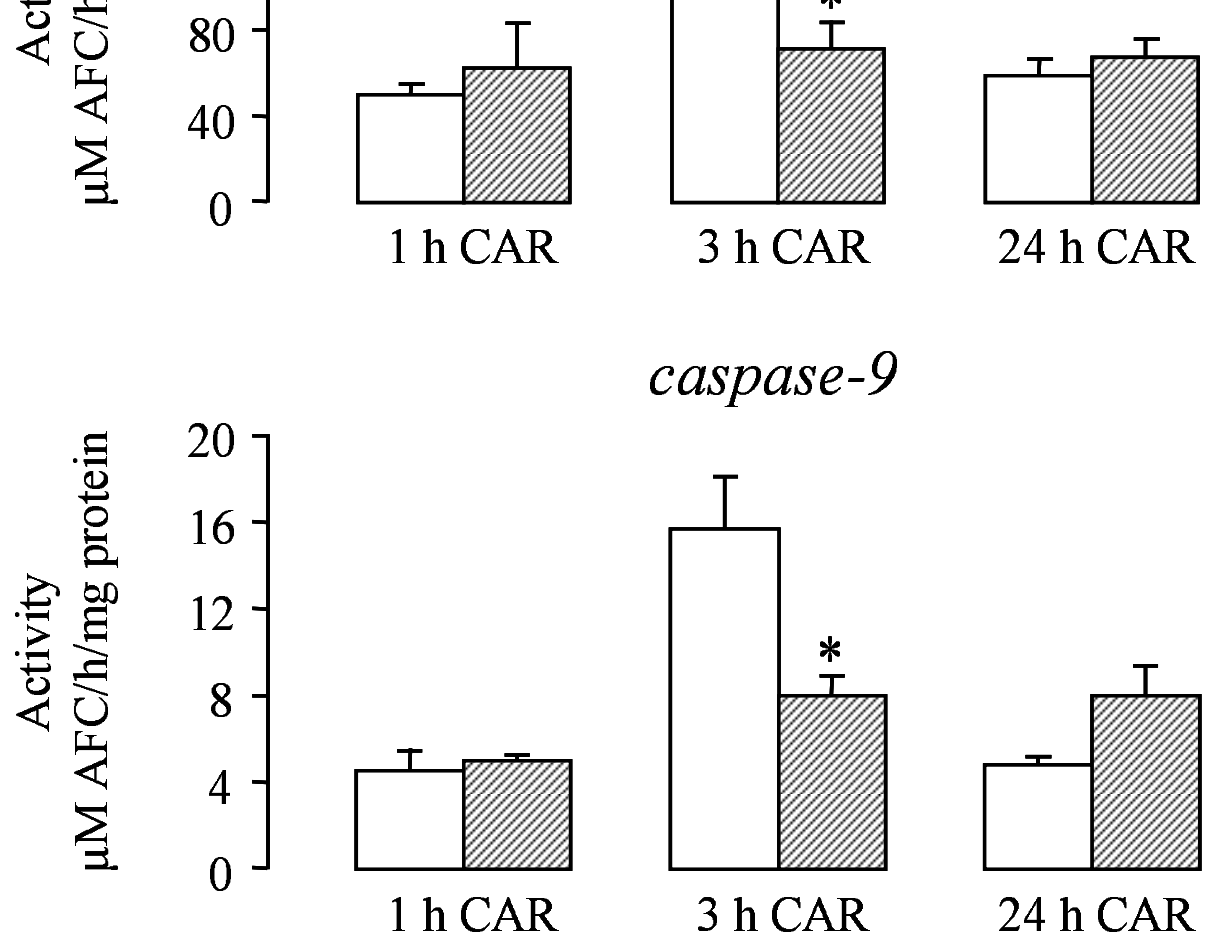

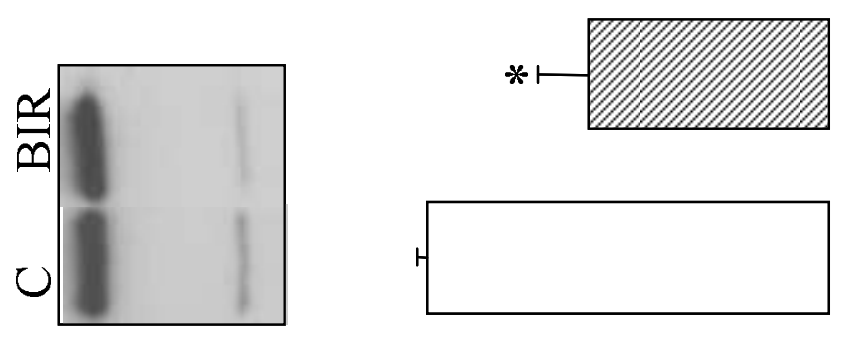

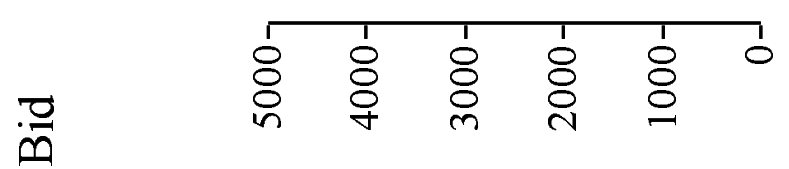
흉 䎡

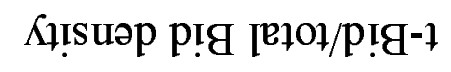
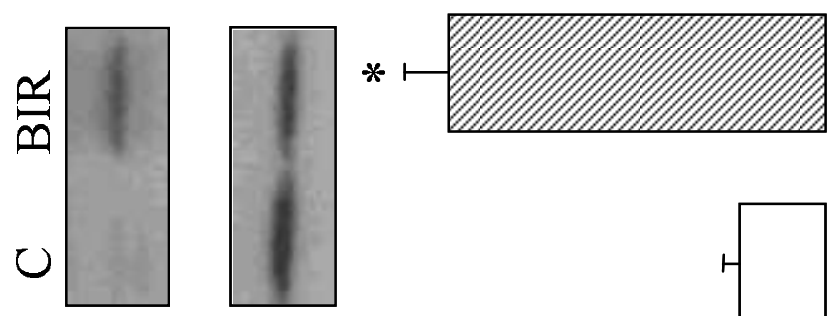

:

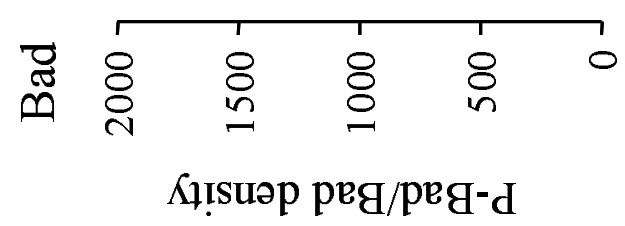

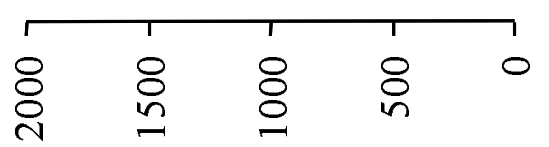

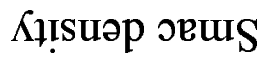

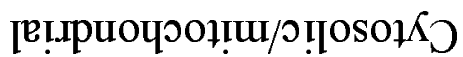
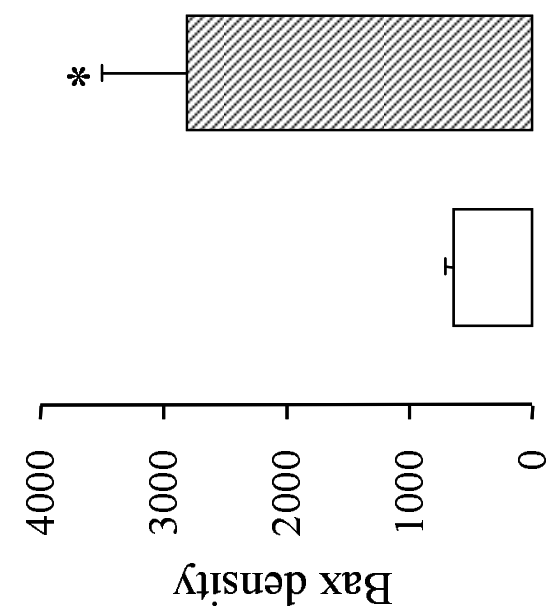

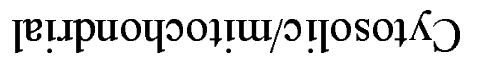

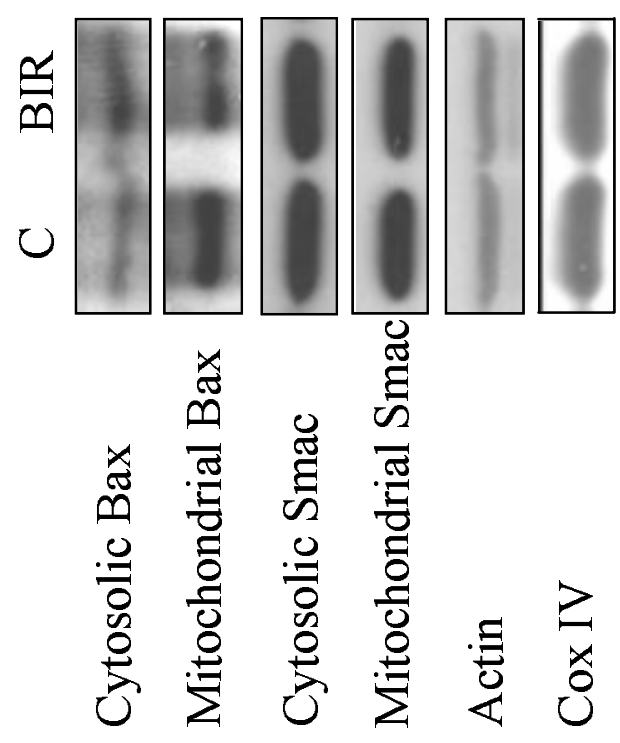

